\title{
AS TRANSFORMAÇÕES DA PAISAGEM NA BACIA DO RIO CARIOCA
}

\author{
SCHLEE, Mônica Bahia \\ Mestre em Estruturas Ambientais Urbanas - Faculdade de Arquitetura e Urbanismo, Universidade de \\ São Paulo - FAU/USP e Mestre em Arquitetura da Paisagem, The Pennsylvania State University - PSU. \\ Professora substituta da Escola de Arquitetura e Urbanismo da Universidade Federal Fluminense. Urbanista \\ e paisagista do Instituto Municipal de Urbanismo Pereira Passos, Prefeitura da Cidade do Rio de Janeiro. \\ E-mail:mbschlee@rio.ri.gov.br
}

\section{CAVALCANTI, Nireu Oliveira}

Doutor em História Social, Instituto de Ciências Sociais e Filosofia - UFRJ, 1997. Professor Adjunto e Diretor da Escola de Arquitetura e Urbanismo da Universidade Federal Fluminense. E-mail: contato@nireu.com

TAMMINGA, Kenneth

Master of Urban and Regional Planning, Queen's University, Canada. Associate Professor, Department of Landscape Architecture, The Pennsylvania State University - PSU. E-mail:krt1@psu.edu

\section{RESUMO}

O objetivo deste artigo é analisar o processo de transformação da paisagem na bacia do Rio Carioca, localizada na cidade do Rio de Janeiro e refletir sobre os principais acontecimentos e conjunturas que delinearam a história ambiental neste vale e sobre o papel dos diferentes agentes sócio-culturais e suas práticas na evolução desta paisagem.

O processo de transformação da paisagem que ocorreu na bacia do Rio Carioca espelha a tensão existente entre a estruturação urbana carioca e a natureza tropical, que não se restringe a esta bacia. O Carioca testemunhou profundas transformações, que reproduzem o que aconteceu na cidade como um todo.

O histórico Rio Carioca foi a primeira fonte de abastecimento d'água para seus habitantes e uma referência paisagística significativa na apropriação, controle e ocupação deste trecho do território carioca. Converteu-se em vetor de expansão urbana em direção às encostas desta bacia, ao longo do caminho das suas águas, e exerceu também um papel importante na regeneração da floresta Atlântica nas encostas do Maciço da Tijuca. Hoje encontra-se à margem da vida da cidade, escondido de seus habitantes.

\section{Palavras-chave: Transformação da paisagem, história ambiental, rio Carioca.}

\begin{abstract}
The purpose of this article is to analyse the process of landscape change along the Carioca River watershed, located within the city of Rio de Janeiro, and reflect on the main events and conjunctures that shaped the environmental history of this valley and on the role of cultural agents and their practices on the evolution of this landscape.

The process of landscape change that occurred in this watershed illustrates the tension between the local urban structure and tropical Nature, which is not restricted to this watershed. The Carioca witnessed profound transformations that reproduce what occurred in the city of Rio de Janeiro as a whole.

The historical Carioca River was the first source of water for Rio's inhabitants and a significant landscape reference in the appropriation, control and occupation of this part of Rio de Janeiro's territory. The river functioned as a vector of urban expansion towards the slopes of the watershed, along its waters pathway, and played an important role in preserving the Atlantic forest on the slopes of the Tijuca Massif. Today, the Carioca is apart of Rio's city life, hidden from its habitants.
\end{abstract}

Key words: Landscape change, environmental history, Carioca river. 


\section{Introdução}

De forma semelhante ao que aconteceu na cidade do Rio de Janeiro como um todo, a transformação da paisagem ao longo do Rio Carioca está intimamente relacionada com as percepções e atitudes da sociedade local em relação à natureza tropical. As práticas de manejo dessa paisagem revelam e representam valores culturais vigentes em diferentes momentos históricos. Padrões diversos de paisagens se sucederam, influenciados por modelos destinados a criar o que se considerava na época "uma cidade ideal", e se justapõem nesta porção do espaço urbano, freqüentemente impondo-se à diversidade ecológica e social carioca.

O Carioca ainda vivo nasce na Serra da Carioca, localizada a nordeste do Maciço da Tijuca, dentro dos limites do Parque do Nacional da Floresta da Tijuca. Este primeiro trecho do rio ainda conserva parte significativa das suas características geomorfológicas originais e vence grandes declividades. Logo após deixar o parque, atravessa a céu aberto uma área favelizada ocupada pela comunidade Guararapes para, em seguida, desaparecer enterrado em maniIhas e ressurgir a céu aberto confinado em grossas muralhas de pedras, construídas no século XIX, em meio a uma área residencial de padrão elevado, o conhecido Largo do Boticário, na confluência entre os bairros de Santa Teresa e Cosme Velho. O padrão de desenvolvimento urbano nesta área é caracterizado pela co-existência de parcelamentos regulares para classes de alto poder aquisitivo (edificações situadas em lotes de grandes dimensões) e assentamentos irregulares ocupados por comunidades de baixa renda. É nesta área onde a retração da floresta tem sido mais dinâmica.

Em seguida, percorre o fundo do vale até a planície costeira, totalmente submerso em galerias sob a densa matriz urbana até desaguar na Baía de Guanabara. Seu trajeto final foi desviado da Praia do Flamengo, sua antiga foz, por uma galeria de cintura a céu aberto construída em 1992. As recentes intervenções realizadas junto à sua foz em 2002 e 2004 não modificaram suas condições paisagísticas e ambientais. Hoje o rio encontra-se à margem da vida da cidade, escondido de seus habitantes na maior parte do seu curso, e continua completamente degradado por despejo de esgoto domiciliar, até desaguar no mar da Baía de Guanabara (ver Figura 1).

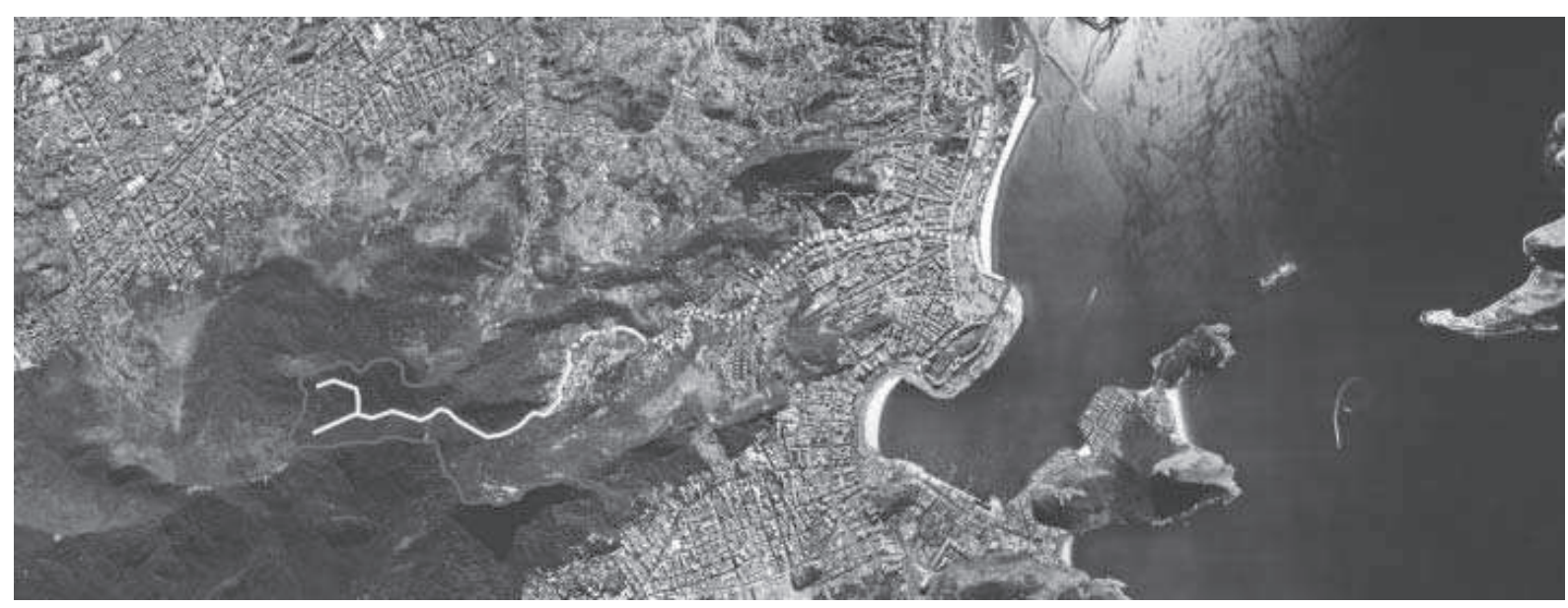

Figura 1: Limites da bacia e traçado atual do rio Carioca

Fonte: Schlee, 2002, sobre Ortofoto 2000 Armazem de Dados/ IPP - PCRJ

No entanto, antes da intensa ocupação urbana da área que hoje conhecemos como Rio de Janeiro, o Rio Carioca apresentava uma configuração morfológica bem diferente da que ele descreve atualmente. Charcos e alagados dominavam a sua planície costeira. Seguindo ao longo da antiga Praia do Sapateiro (atual Praia do Flamengo), em um traçado mais ou menos paralelo à atual Rua do Catete, seguia um pequeno braço intermitente do Carioca chamado Catete, a desaguar junto ao antigo Morro do Leripe (atual Morro da Glória). Neste percurso, o 
Rio Catete separava a planície costeira da planície interior em épocas de cheia, formando uma ilha que ficou conhecida como llha da Carioca. Possuía alguns pequenos braços ao longo do seu trajeto que desaguavam na Praia do Flamengo, funcionando como linhas de drenagem natural nesta planície.

Na confluência entre os rios Carioca e Catete formava-se uma lagoa intermitente, resultado dos extravasamentos periódicos do Carioca, na época das chuvas. Quando isso acontecia, toda a área de entorno se tornava alagada (Barreiros 1965). Esta lagoa foi dos primeiros elementos naturais a ter sua morfologia alterada. Seu gradativo aterro deu origem a uma das primeiras áreas livres da região (ver MAPA 1). De início, usada como área de pastagem, posteriormente configurou-se como praça central desta localidade, conhecida como Largo do Machado. Este espaço livre público viria a constituir, a partir do século XIX, um pólo irradiador do desenvolvimento urbano nesta bacia.

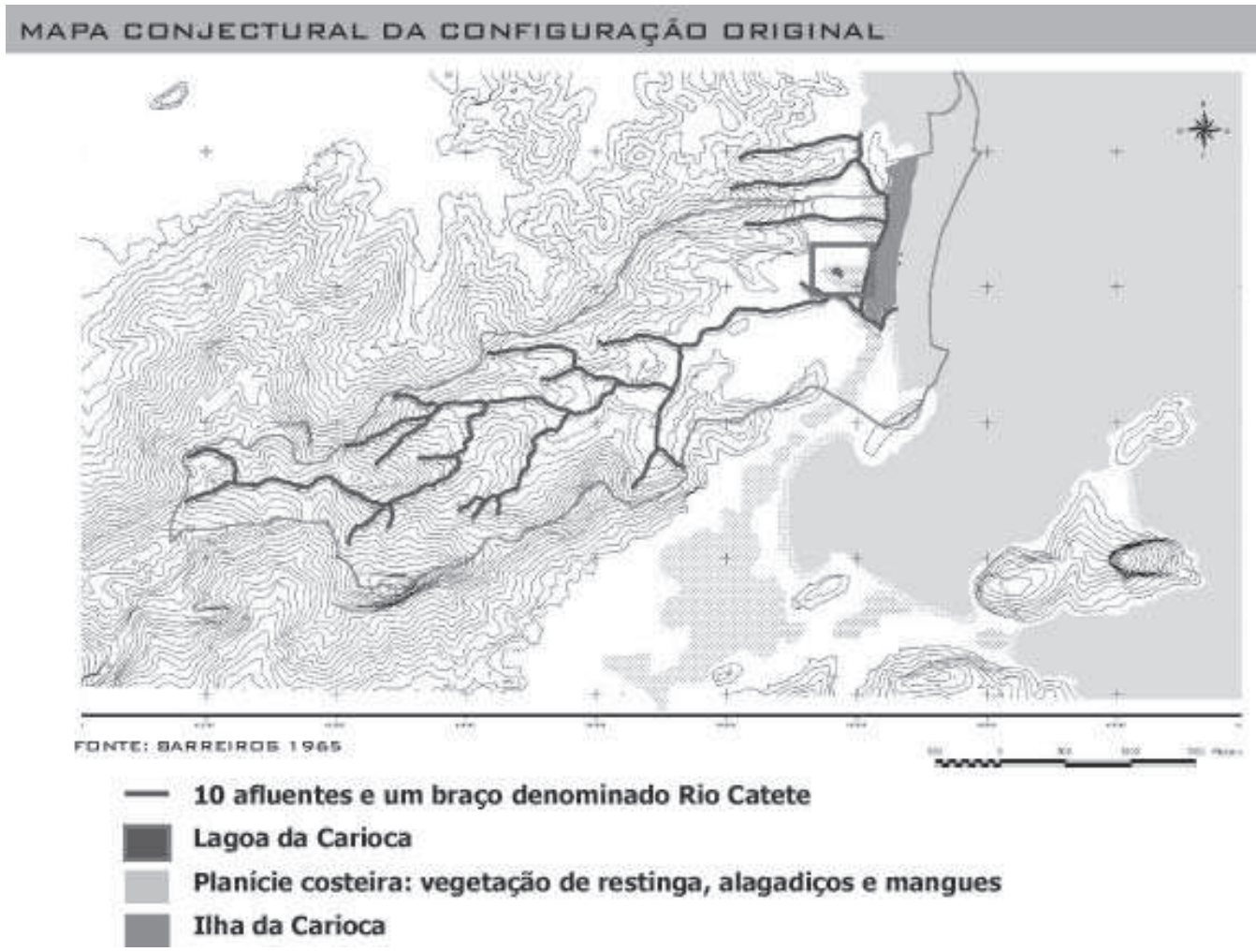

Mapa 1: Mapa conjectural da configuração original do rio Carioca

Fonte: Schlee, 2002, a partir de Barreiros, 1965, sobre levantamento aerofotogramétrico, 1999, Armazem de Dados/ IPP - PCRJ

\section{O encontro de diferentes culturas}

Desde o início do século XVI, a expansão mercantilista européia promoveu o encontro de uma diversidade de culturas nos continentes americanos. Ao chegar à Baía de Guanabara, os europeus encontraram um sistema de valores, rituais e modos de vida completamente distintos dos que conheciam e uma forma diferente de atuar e modificar a paisagem. Seguindo tradições ancestrais, fontes de alimentos e água potável determinavam a escolha da localização dos assentamentos dos habitantes nativos, os quais situavam-se sobre promontórios junto a praias, lagoas, rios e manguezais, preferencialmente na confluência de diferentes ecossistemas (Gaspar 2000, McCann 1999, Dias 1998, Amador 1997).

Nos primeiros trinta anos da presença européia na Baía de Guanabara apenas esporádicos conflitos ocorreram. Segundo Abreu, este foi basicamente um momento de contato, cooperação e troca entre os habitantes nativos e os europeus. $O$ crescente interesse europeu pelo domínio 
do território deu início a uma gradativa mudança na condução deste relacionamento (Abreu 2001).

Na segunda metade do século, as tentativas de estabelecimento de assentamentos franceses na região da Baía de Guanabara contribuíram para acirrar os conflitos entre as diversas etnias. Iniciava-se assim a perseguição aos habitantes nativos pelos portugueses na tentativa de escravizá-los e convertê-los aos hábitos e valores "civilizados", valendo-se das disputas internas entre as tribos locais (Abreu 2001, Dias 1998).

A bacia do Rio Carioca foi palco de grandes disputas travadas pelo domínio da região da Guanabara, devido à presença estratégica do rio, considerado sagrado pelos habitantes nativos e fonte de abastecimento de seus assentamentos. Para os estrangeiros, tratava-se do recurso fundamental para viabilizar futuras formas de ocupação da área, por eles planejadas.

Após o desmantelamento dos assentamentos franceses pelos portugueses, os conflitos entre estes e os nativos "rebeldes" chegaram a termo na região do Carioca na conhecida batalha de Uruçumirim (denominação indígena do Morro da Glória), travada na planície costeira desta bacia. Este episódio propiciou o início da ocupação desta área a partir das soluções urbanísticas utilizadas por Portugal para ocupação das suas novas terras.

Nesta primeira fase de ocupação da cidade, a necessidade de defesa do território, a existência de porto abrigado para auxiliar na circulação de pessoas e mercadorias e boas condições ambientais (presença de água potável e terras passíveis de serem ocupadas sem maiores esforços, nem custos) foram aspectos determinantes na escolha dos sítios que viriam a estabelecer os primeiros núcleos de ocupação. A situação estratégica da orla da Praia do Flamengo e da bacia do Rio Carioca congregava várias destas condicionantes urbanísticas e paisagísticas.

\section{Padrões iniciais de parcelamento e ocupação urbana}

Logo após a fundação da cidade do Rio de Janeiro em 1o de março de 1565, iniciou-se a doação de sesmarias, um dos instrumentos instituídos formalmente em Portugal', usados pelos cristãos na reconquista da Península lbérica aos mouros. As terras foram doadas pelo fundador da cidade, em nome da Coroa Portuguesa, para agentes que viriam a formar um trinômio na ocupação inicial da cidade: a ordem católica Companhia de Jesus, a Câmara Municipal e os membros da expedição de fundação do núcleo inicial (Abreu 2001, Cavalcanti 1997, Macedo 1968, Haddock Lobo 1861).

Segundo o mapa esquemático de autoria de Henrique Beaupaire Rohan, a maior parte da bacia do Rio Carioca pertencia à sesmaria doada à Câmara Municipal, com exceção da área do alto Carioca, em direção à nascente do Rio Comprido no alto da Serra da Carioca, que teria pertencido à Companhia de Jesus (Cavalcanti 2004 e 1997, Arquivo Nacional 1967, Haddock Lobo 1861).

Os padrões de ocupação que tiveram lugar nesta bacia apresentaram características diferentes dos estabelecidos na área central da cidade. No assentamento inicial, os caminhos e lotes bem estreitos haviam sido desenhados para aproveitar as escassas porções de terra seca e segura então disponíveis e servir de ligação entre as igrejas, localizadas no alto dos morros ao longo da costa, o Rio Carioca (então a fonte de abastecimento d'água mais próxima), o atracadouro principal e as fortalezas (Pereira 1996, Bernardes e Soares 1987). Na planície do Carioca, por sua vez, os primeiros caminhos delineados e os primeiros lotes tinham dimensões mais generosas.

A antiga Estrada Real do Catete, que deu origem à atual rua de mesmo nome, foi o primeiro eixo a cortar o vale em direção à região sul, ligando o novo núcleo da cidade, na região do Morro do Castelo, ao Rio Carioca (na época, sua única fonte de abastecimento d' água) e seguindo para o Engenho Real situado às margens da Lagoa de Sacopenupã (atual Rodrigo de Freitas). 
Esta via seguia ao longo do Rio Catete, resguardando uma distância segura das suas margens alagadiças para evitar as freqüentes inundações (Vieira Fazenda 1921 e Barreiros 1965).

Algumas das primeiras sesmarias privadas, doadas aos membros da expedição de fundação ou posteriormente arrendadas à Câmara, deram início à ocupação da planície costeira do vale do Carioca, abrigando grandes propriedades. Inicialmente destinadas a chácaras peri-urbanas para abastecimento da cidade, aos poucos, estas primeiras propriedades foram sendo transformadas em residências de veraneio dos membros da aristocracia local (Cavalcanti in: Folha da Laranjeira, março e abril 1999).

A natureza tropical local, que inicialmente era associada ao domínio dos habitantes nativos e aos perigos iminentes das invasões francesas, com o tempo, passou a ser também associada no imaginário coletivo ao local para onde se dirigiam os escravos afro-brasileiros em fuga do cativeiro (Schlee 2002, Cavalcanti 1997).

\section{Novos agentes, valores e usos - outros caminhos de transformação}

Ao longo dos séculos XVII, XVIII e XIX sucessivos ciclos econômicos no Brasil, sustentados pela exploração humana escrava (índios e, posteriormente, os africanos e seus descentes) e dos recursos naturais locais - cana de açúcar (século XVII), mineração de ouro (século XVIII) e café (século $X I X)$ - ajudaram a talhar progressivamente a vida na cidade e, especificamente, no vale do Rio Carioca, influenciando padrões de ocupação (Abreu 1987). Com a gradativa desintegração do projeto de escravização indígena, a economia em desenvolvimento da colônia estimulou a importação de contínuas e maciças ondas de africanos escravizados para trabalhar, em princípio, nos engenhos e, mais tarde, nas fazendas de café (Florentino 1995).

Já a partir do século XVII, os escravos de origem africana eram os principais usuários dos espaços públicos no cotidiano colonial, funcionando inclusive como elementos fundamentais na infra-estrutura urbana. Estes eram responsáveis pelo abastecimento de água nas residências e pelo despejo dos dejetos caseiros, que habitualmente eram lançados no rio ou alagadiço mais próximo.

A religião africana foi um fator fundamental para a apropriação da natureza tropical pelos recém chegados e um dos traços desta cultura mais profundamente enraizados na cultura local. Esta religião guarda uma forte relação com a natureza, baseada em representações simbólicas de seus elementos como entidades míticas. A floresta costumava abrigar rituais e oferendas sagradas aos deuses africanos, além de servir como refúgio aos afro-brasileiros em fuga do cativeiro.

Para esta parte numerosa da população, ainda que marginalizada, a natureza local era vista como abrigo e conexão com sua cultura anterior. Para a classe dominante, a natureza local inspirava apenas medo e aversão, pois continuava associada a perigos, e a usos e condutas consideradas não apropriadas ou não civilizadas (Vianna 1993, Cezar in: Cruz 1992, Santos 1981).

A chegada da Corte Portuguesa em 1808, em refúgio às invasões napoleônicas na Europa, deu início a um período efervescente de desenvolvimento urbano no Rio de Janeiro (Abreu 1987). A instalação de propriedades da família real e de membros da aristocracia no entorno do Largo do Machado induziu a uma progressiva valorização desta área e de seu entorno.

A promulgação, neste mesmo ano, de um imposto sobre a propriedade urbana conhecido como Décima Urbana ${ }^{2}$, reconfigurou os limites urbanos estabelecidos até então, com objetivo de expandir a área sujeita à taxação. Os limites urbanos expandiram-se em direção à zona sul da cidade, anexando toda a área da bacia do Carioca (Cavalcanti 1997). A paisagem local testemunhou a transformação que se consolidaria na primeira metade do século XIX, onde a prevalência dos usos rurais deram lugar a usos mais urbanos. 
A partir da década de 1810, os padrões de desenvolvimento e uso da terra na planície costeira do vale do Carioca começaram a responder à presença das propriedades reais nesta área, iniciando sua valorização. As primeiras ruas secundárias começaram a ser abertas. $\bigcirc$ desmembramento de diversas chácaras que produziam alimentos em propriedades menores conduziu à transformação gradativa do tecido peri-urbano existente em uma malha urbana que se estruturava para uso da aristocracia local emergente.

O desenvolvimento urbano não se restringiu à planície, foi progressivamente alcançando as encostas do Maciço da Tijuca, tendo como eixo de penetração o traçado do Rio Carioca. A economia cafeeira que avançava sobre as encostas do vale, tornou-se base de sustentação da reestruturação urbana da planície, necessária para abrigar a elite que nela começava a se instalar, e, simultaneamente à extração de lenha, abriu caminho para a ocupação urbana das encostas. Nesta fase da ocupação, o Rio Carioca funcionava como marco referencial que definia os limites frontais destas propriedades. Os limites posteriores eram, na sua maioria, fixados ao longo da linha dos divisores da bacia.

A freqüente ocorrência de epidemias, que se espraiavam por toda a densa malha colonial, começou gradativamente a estimular o desenvolvimento urbano em direção às áreas periféricas do núcleo central da cidade e das encostas de seus vales. Ao final do século XIX, 29 chácaras recortavam o vale do Rio Carioca (ver Mapa 2), ocupando quase toda a área do vale até aproximadamente 400m acima do nível do mar (Cavalcanti 1999, 1997, Resende 1999, Vianna 1993).

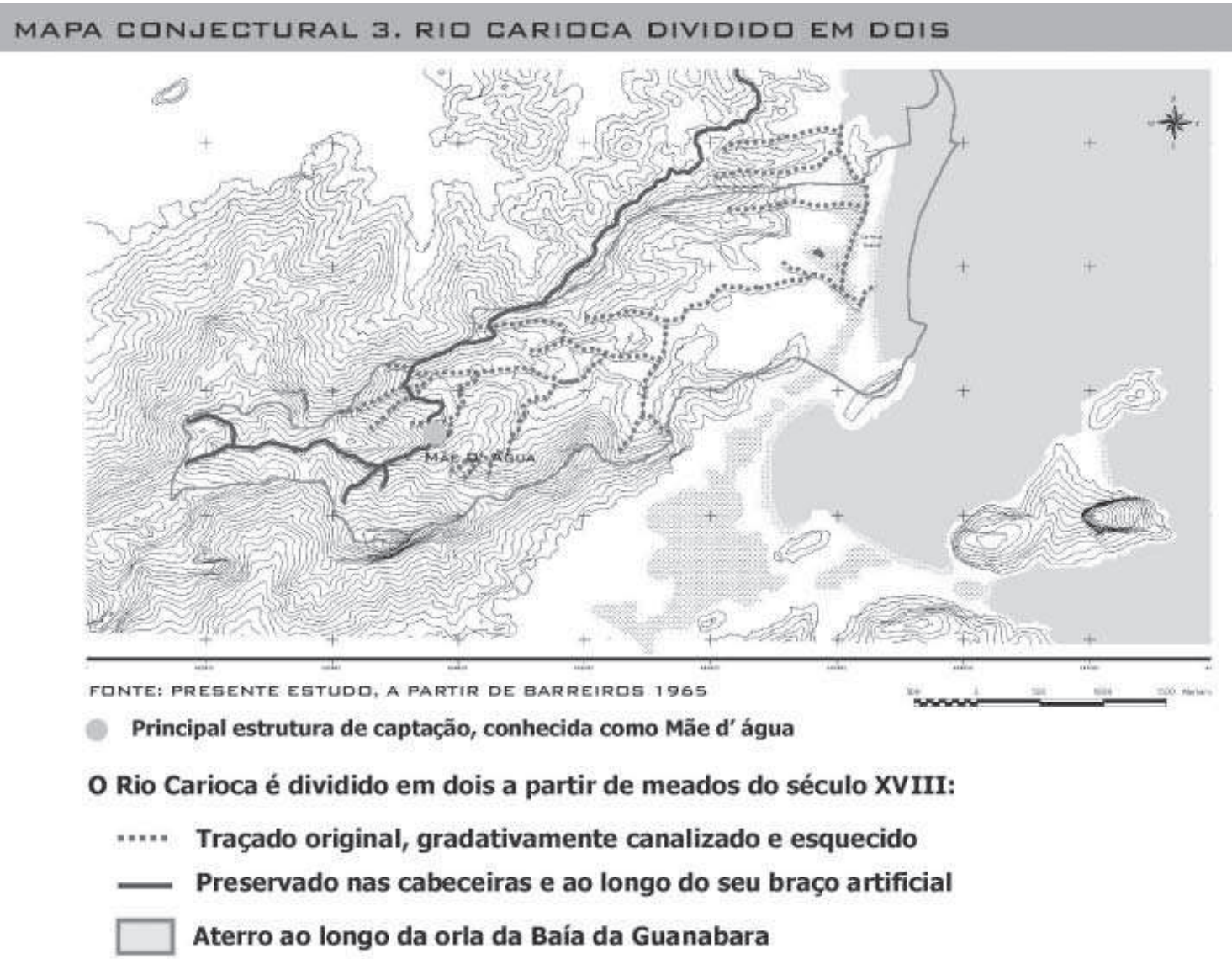

Mapa 2: Mapa conjectural da localização das chácaras na bacia do rio Carioca ao final do século XIX Fonte: Cavalcanti, 1999, sobre levantamento aerofotogramétrico, 1999, Armazem de Dados/ IPP - PCRJ

As contínuas expedições e missões estrangeiras durante o século XIX, e a eventual permanência de estrangeiros que optavam freqüentemente por habitar as encostas do Maciço da Tijuca (Graham 1990) foi, aos poucos, disseminando entre a classe dominante um outro tipo de relação 
com a natureza tropical local, a par e passo, ainda que com menor destaque, do processo de penetração na cultura local dos hábitos e valores das classes marginalizadas.

A implantação da fábrica de tecidos Aliança em 1880 e, posteriormente, seu fechamento em 1937, após a implantação do zoneamento industrial pelo decreto 6000/1937, tiveram impactos significativos na área do vale do Carioca. A instalação da vila operária nas proximidades da fábrica fez com que novos agentes, hábitos e valores fossem incorporados à vida urbana do vale, mas seu abandono deixou como herança o início da ocupação das suas encostas por estratos sociais de baixa renda, que procuravam garantir moradia próxima aos locais de trabalho.

Tanto a fábrica como a vila operária, localizadas nas imediações da atual Rua General Glicério, foram demolidas para dar lugar a um conjunto de edifícios residenciais de padrão elevado. Após a desativação da fábrica, 1600 trabalhadores foram forçados a se estabelecer em outro lugar. Aqueles que não rumaram para a zona norte da cidade, ocuparam gradativamente as encostas do vale, dando origem ou aumentando os contingentes das favelas Vila Imaculada Conceição e Vila Cândido (1931), Morro Azul (1936), Guararapes (1937), Cerro-Corá (1941) e Vila Pereira da Silva (1946) (GEOHECO-UFRJ/SMAC-PCRJ 2000, Vianna 1993, Aquino 1990).

A água como agente de proteção: a aceitação da natureza na cidade e o renascimento da floresta tropical nas encostas do Maciço da Tijuca

Principal fonte de abastecimento d'água da cidade do Rio de Janeiro até meados do século XIX, - Carioca chegou a ter todo o seu trajeto protegido por atos legislativos que vigoraram entre o início do século XVII (1611 e 1638) até a metade do século XVIII (Cavalcanti 1997). O processo de transformação da morfologia do Rio Carioca iniciou-se com a construção do definitivo aqueduto, que conduzia as águas do alto Carioca até o chafariz inaugurado em 1723, no atual Largo da Carioca. A partir desse primeiro chafariz, foram construídos ramais que distribuíam suas águas em fontes públicas localizadas nas principais praças da área central da cidade.

Este braço artificial do Rio Carioca, que seguia pelas encostas de Santa Teresa, consolidou-se a partir de meados do século XVIII, com o término das obras de estabilização estrutural do aqueduto e das instalações definitivas da estação de captação, conhecida como Mãe D'Água, situada a 200 m acima do nível do mar (Cavalcanti 1997, Abreu 1992, Magalhães Correa 1939).

Esta obra configurou-se na primeira iniciativa de transposição de uma bacia hidrográfica que se tem notícia no Brasil. Desde então, o rio foi dividido em dois (Mapa 3). As nascentes continuaram protegidas, pois sua integridade era necessária para garantir o abastecimento da cidade. O restante do rio foi sofrendo gradativas alterações na sua forma, função e na qualidade de suas águas.

Se o rio conseguiu manter parte do seu trajeto protegido, a floresta que encobria as encostas do vale sofreu graves perdas neste período. Entre meados dos séculos XVIII e XIX, grande parte das encostas do Maciço da Tijuca foram desmatadas, seja devido à extração de lenha, seja devido à disseminação do cultivo do café nas encostas do maciço, afetando até mesmo os mananciais aí existentes. Com a implantação do sistema de captação das águas do Rio Maracanã em 1850, as águas do Carioca foram perdendo gradativamente seu domínio utilitário para a cidade do Rio de Janeiro.

O aumento progressivo da necessidade de abastecimento d'água devido ao crescimento contínuo da população carioca ao longo do século XIX, agravado pelas freqüentes inundações na cidade e a aceleração de processos erosivos nas encostas do Maciço da Tijuca, pressionaram o governo imperial a estabelecer um programa de proteção às florestas e mananciais dos principais rios do Maciço da Tijuca no período entre 1840 e 1890. Ações de reflorestamento e desapropriações das fazendas de café localizadas nas encostas mais íngremes do maciço foram implementadas para proteger as nascentes e cabeceiras dos seus principais rios (entre os quais o Carioca e o 
Maracanã). A recomposição da floresta do Maciço da Tijuca deu origem ao Parque Nacional da Tijuca, criado em 1961, pelo governo federal (GEOHECO-UFRJ/SMAC-PCRJ 2000, Heynemann 1995, Abreu 1992, Cezar in: Cruz 1992).

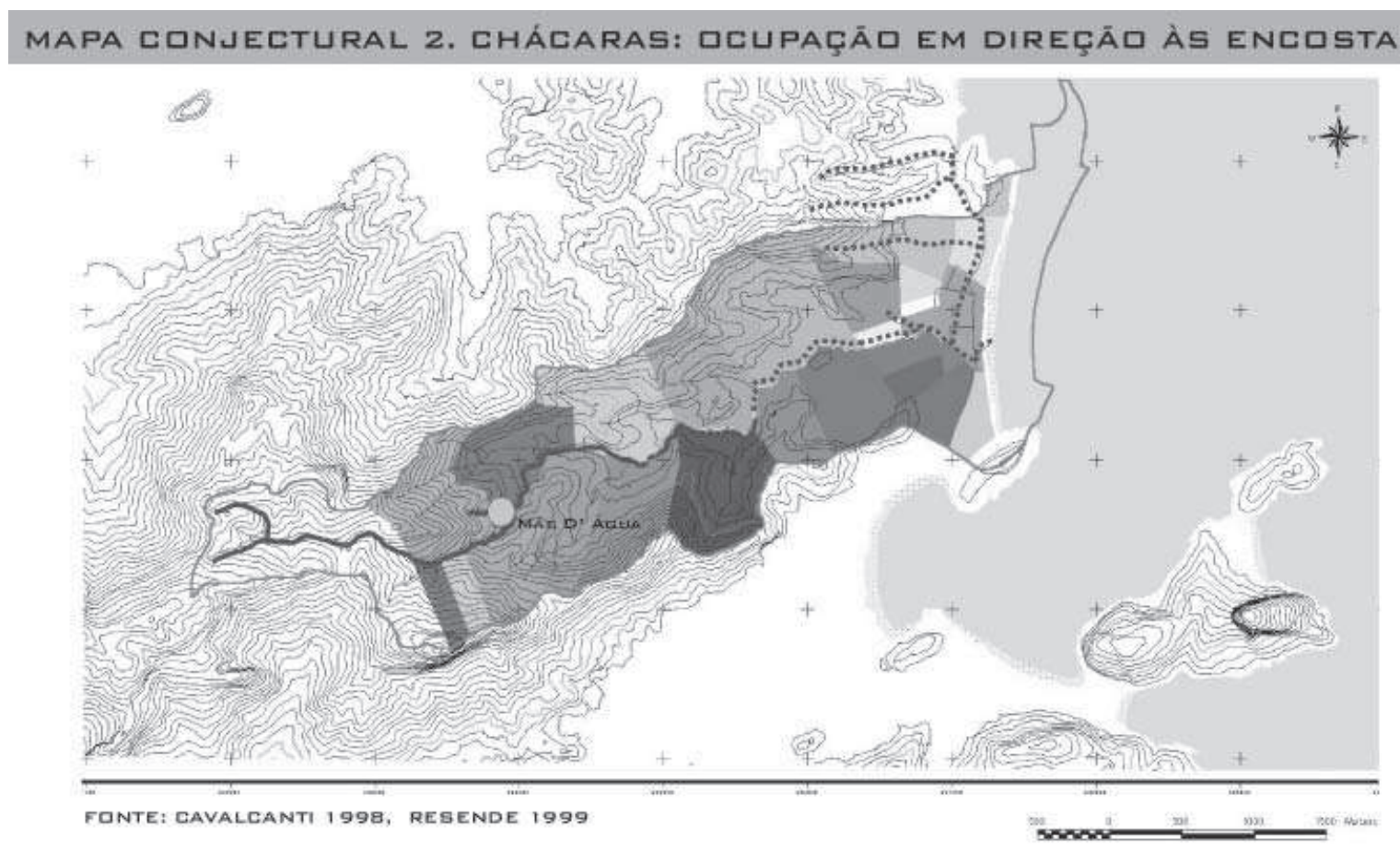

Final do século XIX: Subdivisão do vale em 29 propriedades

L Limites frontais dos lotes definidos pelo Rio Carioca

_ Limites de profundidade dos lotes definidos pelos divisores da bacia

..... Trecho do Carioca e afluentes já canalizados a céu aberto na época

Mapa 3: O Carioca dividido em dois

Fonte: Schlee, 2002, a partir de Barreiros, 1965, sobre levantamento aerofotogramétrico, 1999, Armazem de Dados/ IPP - PCRJ

O reflorestamento das encostas do Maciço da Tijuca foi coordenado pelo Major Manuel Gomes Archer que, segundo Heynemann, executou o plantio de setenta mil árvores entre $1862 \mathrm{e}$ 1887 com uma equipe formada por escravos afro-brasileiros (Heynemann 1995, Abreu 1992) e grupos autônomos contratados. Na mesma época, Tomás Nogueira da Gama, administrador da Floresta das Paineiras, ficou encarregado de manter as nascentes do Carioca, restaurando esta floresta nas áreas que apresentassem clareiras no trecho das Paineiras. Nogueira da Gama executou o plantio de vinte mil árvores durante o mesmo período (Cezar in: Cruz 1992).

Esta iniciativa foi encampada pela elite local com a intenção de construir uma nova identidade para a capital do império e fomentar a noção de civilidade na sociedade carioca, utilizando como símbolo o elemento natural local. Sem dúvida, esta intervenção guardava ainda em sua origem uma preocupação utilitarista com o resgate dos recursos que se escasseavam. Estas décadas marcaram uma mudança de direção no manejo do Rio Carioca, uma fase de aceitação da natureza na cidade. Mas foi também um período extremamente representativo da tensão que se estabelecia no imaginário coletivo carioca entre as perspectivas metafísicas e utilitárias da natureza tropical (Schlee 2002, Heynemann 1995).

274 Embora admirada e empregada como modelo estético para os desenhos paisagísticos que se implantaram nesta época na cidade, a representação da natureza que era aspirada dentro dos limites urbanos não provinha da natureza tropical local, antes derivava-se de uma visão romântica de natureza, baseada em uma estética de inspiração inglesa (Schlee 2002, Segawa 1996, 
Crandell 1993). Este partido foi adotado nas reformas e construções dos principais parques e praças da cidade entre as décadas de 1860 e 1890, tendo sido adotado também no redesenho do Largo do Machado, elaborado por Auguste François Marie Glaziou, em 1872.

\section{Os efeitos das teorias médicas e das tecnologias de infra-estrutura urbana emergentes na manipulação da paisagem}

O século XX testemunhou um claro distanciamento entre a cidade e a natureza local, impulsionados pela consolidação do capitalismo. A floresta nas vertentes íngremes do vale foi aos poucos se recompondo, mas o Rio Carioca não teve a mesma sorte. Canalizado a céu aberto desde sua porção média até a foz ao longo das décadas de 1840 e 1850 (Schlee 2002, Cavalcanti 2001 e 1997, AGCRJ, códice 32-1-32), o rio foi enterrado em galerias subterrâneas inauguradas em 1905, que o conduzem até hoje, à margem da vida da cidade, até a Baía da Guanabara.

Esta última intervenção foi parte de um conjunto de reformas urbanas executadas pela administração Pereira Passos no Rio de Janeiro na virada do século, com o objetivo de associar a capital do país ao conceito de Modernidade, construindo o que se considerava ser uma cidade ideal, civilizada, ordenada e associada à noção de progresso (Carvalho 1994). Como parte destas intervenções, as ruas do vale foram progressivamente alargadas, pavimentadas com asfalto e arborizadas (Gerson reedição 2000, Rezende 1999, Reis 1977).

Este processo foi amplamente sustentado pelas teorias higienistas aplicadas ao ambiente urbano e pelas novas tecnologias urbanas que emergiam rapidamente. Inicialmente propostas pelos médicos sanitaristas ${ }^{3}$ e, posteriormente, encampadas pelos engenheiros urbanistas, este novo enfoque passou a orientar as ações do poder público no tratamento das áreas urbanas. A floresta foi novamente abandonada e elementos que compunham a paisagem urbana local, como a malha urbana colonial considerada obsoleta, a falta de circulação de ar nas ruas estreitas e nos cômodos residenciais sem ventilação, os manguezais, pântanos e alagadiços em geral, e a pobreza que lotava cortiços e estalagens, foram considerados alvos a serem erradicados (Szczygiel e Hewitt 2000, Schlee 2002, Cavalcanti 1997, Carvalho 1994, Benchimol 1991).

Formuladas a partir das análises da Comissão de Melhoramentos (1874 a 1876), três linhas de

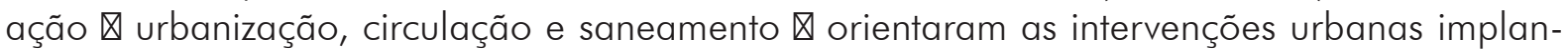
tadas no início do século XX no Rio de Janeiro. Estas diretrizes também passaram a orientar a ocupação da bacia do Rio Carioca.

O vale do Rio Carioca, que já nesta época era considerado um lugar privilegiado, próximo à área central da cidade e que mantinha uma boa qualidade de vida, começou a sofrer com a progressiva pressão urbana em direção a cada vez mais valorizada zona sul da cidade. Paralelamente, a implantação gradual das novas tecnologias de infra-estrutura urbana $\bigotimes$ os sistemas de gás (1865), esgotamento (1864), bondes (1868) e água (1876) \ equiparam progressivamente o vale para abrigar a emergente burguesia carioca (Pereira 1996, Abreu 1987). O desenvolvimento urbano rumo às encostas ganhou novo impulso com a instalação destes serviços de infraestrutura e do sistema de bondes a partir da segunda metade do século XIX.

O manejo da paisagem local neste período reflete claramente a intenção de dominar e controlar a natureza. A tensão pendia, uma vez mais, em direção à visão utilitarista e de exploração dos recursos naturais sem que houvesse uma preocupação com a sua regeneração (Schlee 2002). As necessidades sociais dos diversos estratos da população também não foram consideradas e, à classe operária, só restou deixar o vale ou se dirigir às encostas.

O corte parcial do morro Novo Mundo em 1914 (FIGURA 2), para possibilitar novas ligações com a região sul da cidade, e a remoção gradativa das comunidades pobres e indústrias das 
áreas consideradas valiosas na cidade, entre as décadas de 1940 e 1960, foram também norteadas por esta mesma lógica.

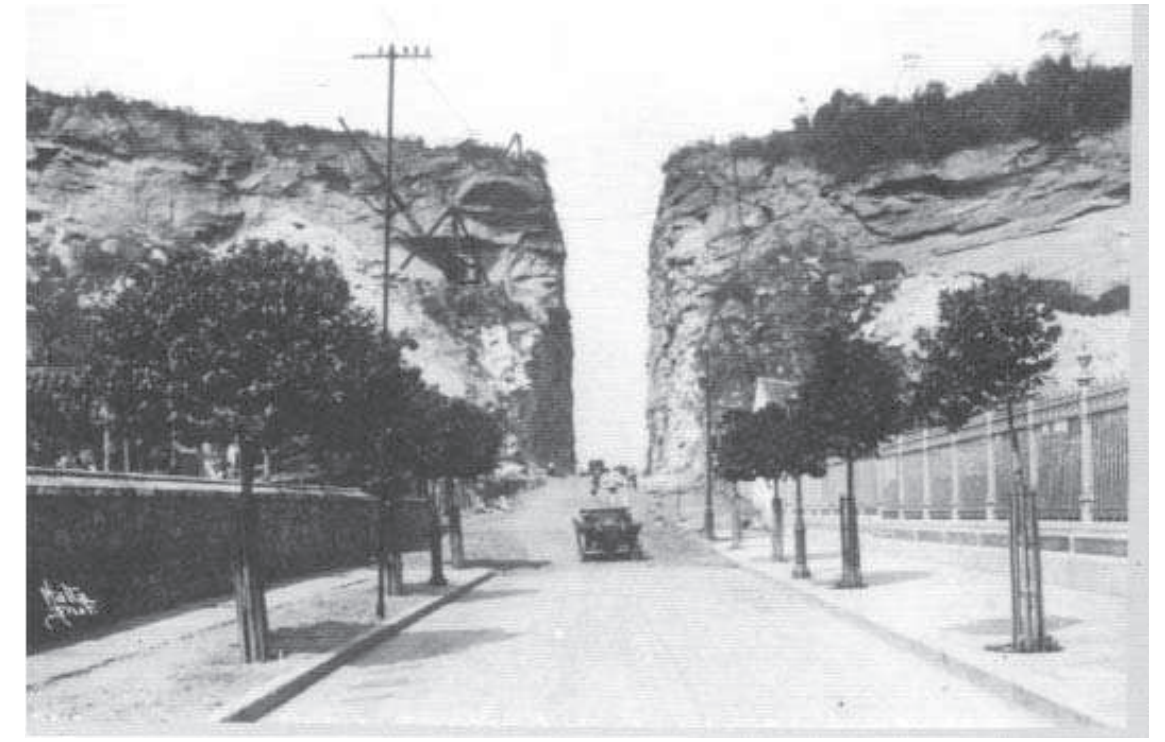

Figura 2: Corte do Morro Novo Mundo

Fonte: AGRJ (Augusto Malta, 1914)

\section{A cidade superposta à natureza tropical}

A consolidação do Movimento Moderno Brasileiro e a influência norte-americana promoveram grandes impactos no urbanismo carioca a partir de meados do século XX. A priorização à circulação viária produziu a proliferação de vias expressas, túneis e viadutos que recortaram o tecido urbano carioca com o objetivo de conectar mais rapidamente as zonas norte, centro e sul.

Na bacia do Carioca, o padrão urbanístico adotado não foi diferente. Em prosseguimento à reestruturação da orla da Praia do Flamengo durante os primeiros anos do século XX, a execução do aterro ${ }^{4}$ entre 1954 e 1965 possibilitou a implantação de diversas vias expressas junto à orla da baía, conjugadas ao Parque Brigadeiro Eduardo Gomes, conhecido como Parque do Flamengo (Figura 3). Entre as décadas de 1960 a 1970, a abertura dos túneis Santa Bárbara e Rebouças e dos corredores viários e viadutos que atravessam o vale e dão acesso aos túneis produziram novos cortes transversais na paisagem local (Figura 4).

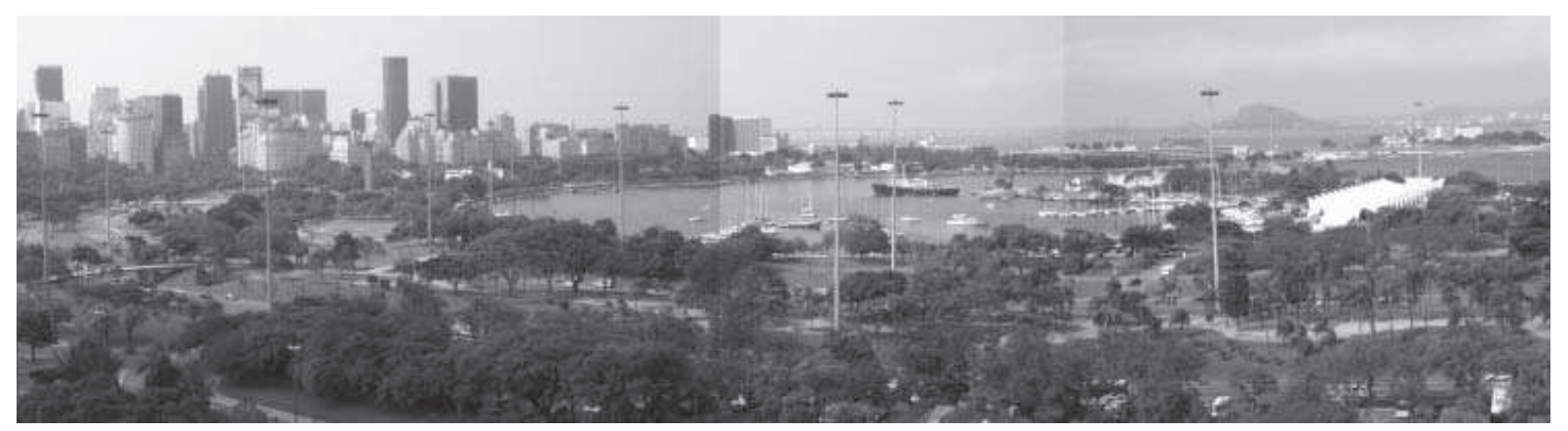

Figura 3: Parque do Flamengo

Foto: Schlee, outubro 2005

Estes eixos viários seccionaram o vale em quatro fragmentos paisagísticos estanques, com características diferenciadas (Schlee, no prelo), e promoveram o adensamento populacional, estimulando a supervalorização do ambiente construído em detrimento do ambiente natural no qual este se insere. 


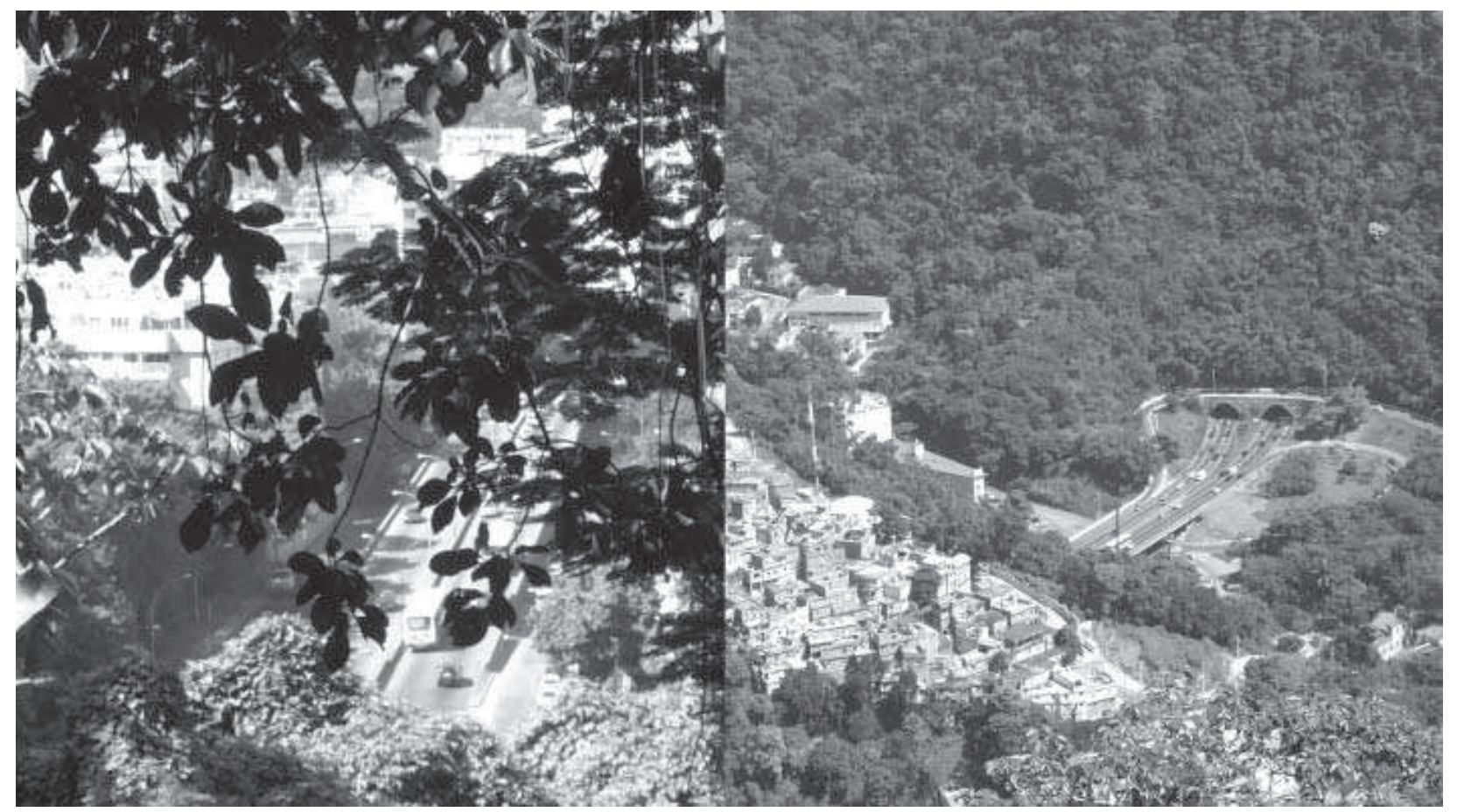

Figura 4: Túneis Santa Bárbara e Rebouças, respectivamente

Fotos: Schlee, abril 2006

No entanto, a implantação do parkway em 1965 possibilitou a criação do primeiro espaço livre público destinado à recreação de grandes massas. $O$ desenho original e o uso que a população carioca fez do Parque do Flamengo marcaram uma nova fase na concepção dos equipamentos públicos de lazer no Rio de Janeiro. A sua criação, concebida para recreação ativa de faixas etárias e classes sociais diversas, inaugurou a inserção da diversidade social nos espaços livres públicos cariocas. Como havia acontecido nos Estados Unidos e na Europa, segundo Ward Thompson (1998), esta nova concepção trazia em si uma visão moralizante do contato com uma natureza "urbanizada" com a intenção de educar "socialmente" as massas. Apesar da pouca relevância em termos ecológicos, a composição paisagística inovadora e a socialização do uso de um espaço livre público urbano destinado ao lazer de grandes massas foram dois grandes legados desta significativa intervenção urbana.

O processo de verticalização da arquitetura promovido com o apoio da legislação edilícia estabelecida a partir do final da década de 1930 (Decreto 6000/1937) aconteceu de forma mais sistemática na planície do Carioca, área que se valorizou ainda mais depois da implantação do Parque do Flamengo. No entanto, este processo não ficou circunscrito à orla, ocorreu também ao longo do fundo do vale do Carioca, junto ao principal eixo longitudinal de penetração. Este eixo de ocupação, que se consolidou a partir do século XVII, sofreu um grande impacto com a implantação dos três corredores viários transversais ao vale, acelerando o processo de avanço e superposição da malha urbana sobre a floresta local: o eixo viário na orla da Baía de Guanabara, formado pelas vias expressas ao longo do Parque do Flamengo; a Rua Pinheiro Machado, eixo viário interno de grande movimento diário, localizado ainda na planície do vale, que dá seqüência ao túnel Santa Bárbara em direção a Botafogo e o eixo formado pelo complexo viário do túnel Rebouças, localizado acima da cota 50.

O tipo morfológico que predominou na área da planície costeira e ao longo do eixo longitudinal foi a implantação da quadra tradicional européia (a quadra-bloco), onde as fachadas dos edifícios formaram planos verticais contínuos, negligenciando as condições climáticas e ambientais locais e deram origem a quarteirões compactos, superedificados e superpovoados (Menneh 1997). 
O decreto 6000 de 07/01/1937 institucionalizou o edifício de apartamentos como um novo tipo de habitação multi-familiar na cidade. Segundo Vaz (1994), esta tipologia passou a ser associada pelos agentes da especulação imobiliária ao conforto, à modernidade e, principalmente, a um novo símbolo de status social. A possibilidade de edificar 10 pavimentos ou mais, dependendo da largura das vias, deu início à febre construtiva que teve lugar no vale do Carioca a partir da década de 1940.

O aumento do valor da terra levou a sucessivas modificações na legislação urbanística (decretos 8547 de 1946, 9002 de 1947, 3800 de 1970, 322 de 1976 e 3155 de 1981: PCRJ-Código de Obras, edição 2000). Paralelamente, e não por acaso, a ocupação informal se consolidou no mesmo período, avançando progressivamente sobre as encostas da bacia (FIGURA 5).

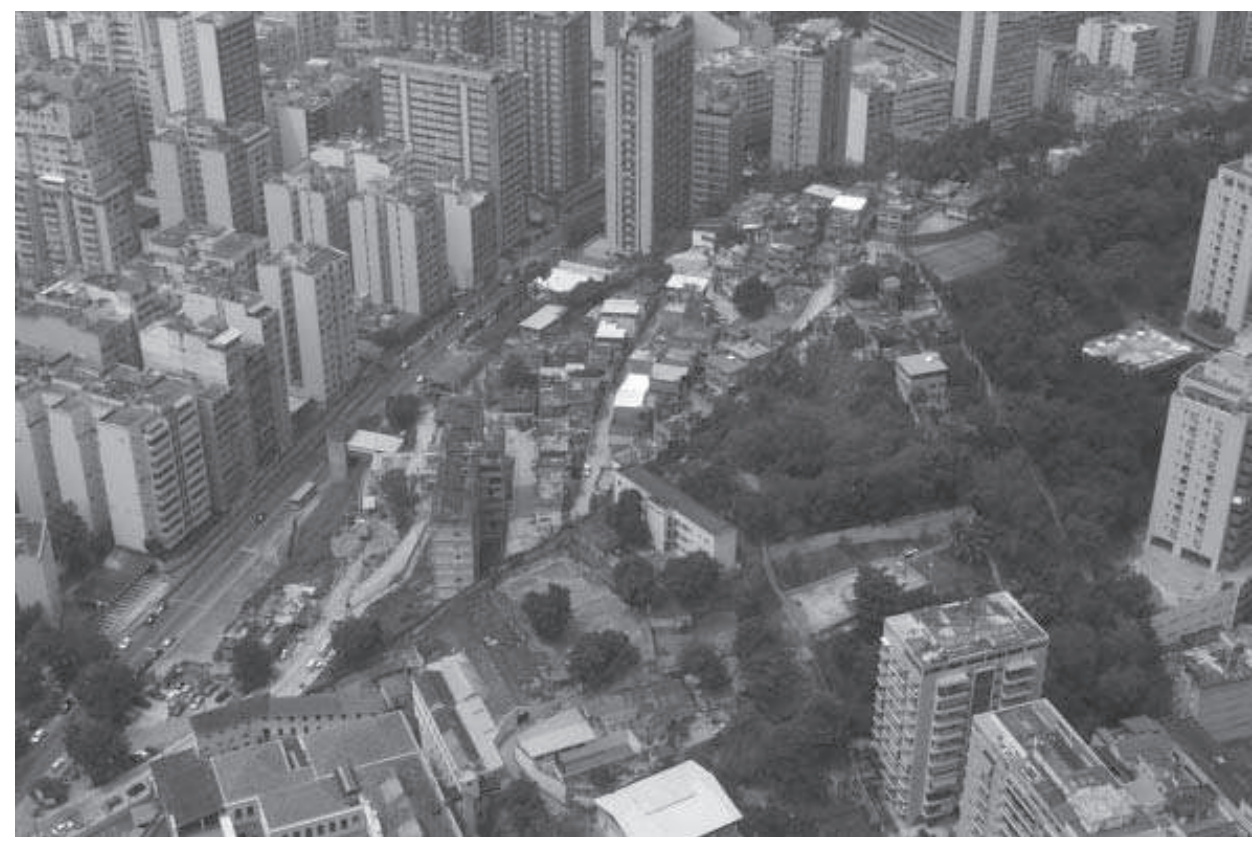

Figura 5: Verticalização da arquitetura formal e consolidação da ocupação informal: processos simultâneos. Foto: Schlee outubro 2002

Estes decretos propiciaram o aumento progressivo da densidade urbanística e dos gabaritos vigentes, principalmente nas áreas mais valorizadas da bacia do Carioca, tendo como conseqüência o crescimento da densidade populacional e construtiva na bacia, e a ruptura dos padrões de ocupação existentes. Como desdobramento deste processo de desenvolvimento desenfreado, a proliferação das favelas nas encostas da bacia acelerou o processo de retração da floresta.

A legislação urbanística foi um dos mais impactantes agentes de transformação na paisagem desta bacia. $O$ efeito causado pelos processos desenfreados de verticalização da arquitetura formal e de favelização sobre a infra-estrutura urbana local também foi muito grande. Redes de drenagem, esgotamento sanitário e o sistema de transporte local não acompanharam o ritmo das construções formais nem dos assentamentos informais. A paisagem local sofreu uma transformação radical em conseqüência destes processos que ainda estão em curso.

\section{O processo de conscientização da sociedade local em relação às questões ambientais}

278 A preocupação com a questão ambiental atingiu a população do vale do Rio Carioca a partir do início dos anos 1980. Organizações não governamentais locais atuaram na época em iniciativas pontuais de reflorestamento das encostas e na arborização das ruas do vale, pressionando o poder público municipal a desistir da abertura de um novo eixo viário (a chamada "via paralela", 
que ligaria a Rua Soares Cabral à Praça Ben Gurion) e a desentupir as galerias subterrâneas do Rio Carioca, obstruídas devido ao despejo de resíduos sólidos no leito do rio e nas galerias de drenagem que deságuam nele.

Em âmbito municipal, leis preservacionistas estabelecidas a partir de 1984 propiciaram a criação de várias áreas de proteção ambiental na bacia do Carioca (ver MAPA 4). Foram instituídas a Área de Preservação Ambiental de Santa Teresa (1984), o Parque Municipal Eduardo Guinle (1989), a Área de Preservação Ambiental de São José (1991), a Área de Preservação Ambiental do Cosme Velho e Laranjeiras (de 1991), a Área de Preservação Ambiental e Recuperação Urbana do Alto da Boa Vista (1992, que ainda não foi regulamentada) e a Área de Preservação Ambiental no entorno às Casas Casadas (1994). Mais recentemente, foi instituída a Área de Preservação do Ambiente Cultural de Laranjeiras (de 2001), que protegeu, ainda que de forma pontual, o patrimônio construído e as pequenas reservas florestais que resistiram, nos fundos dos quintais residenciais e das antigas chácaras, como a que pertenceu ao Conde Modesto Leal, ou ainda dos edifícios ao longo da Rua das Laranjeiras.

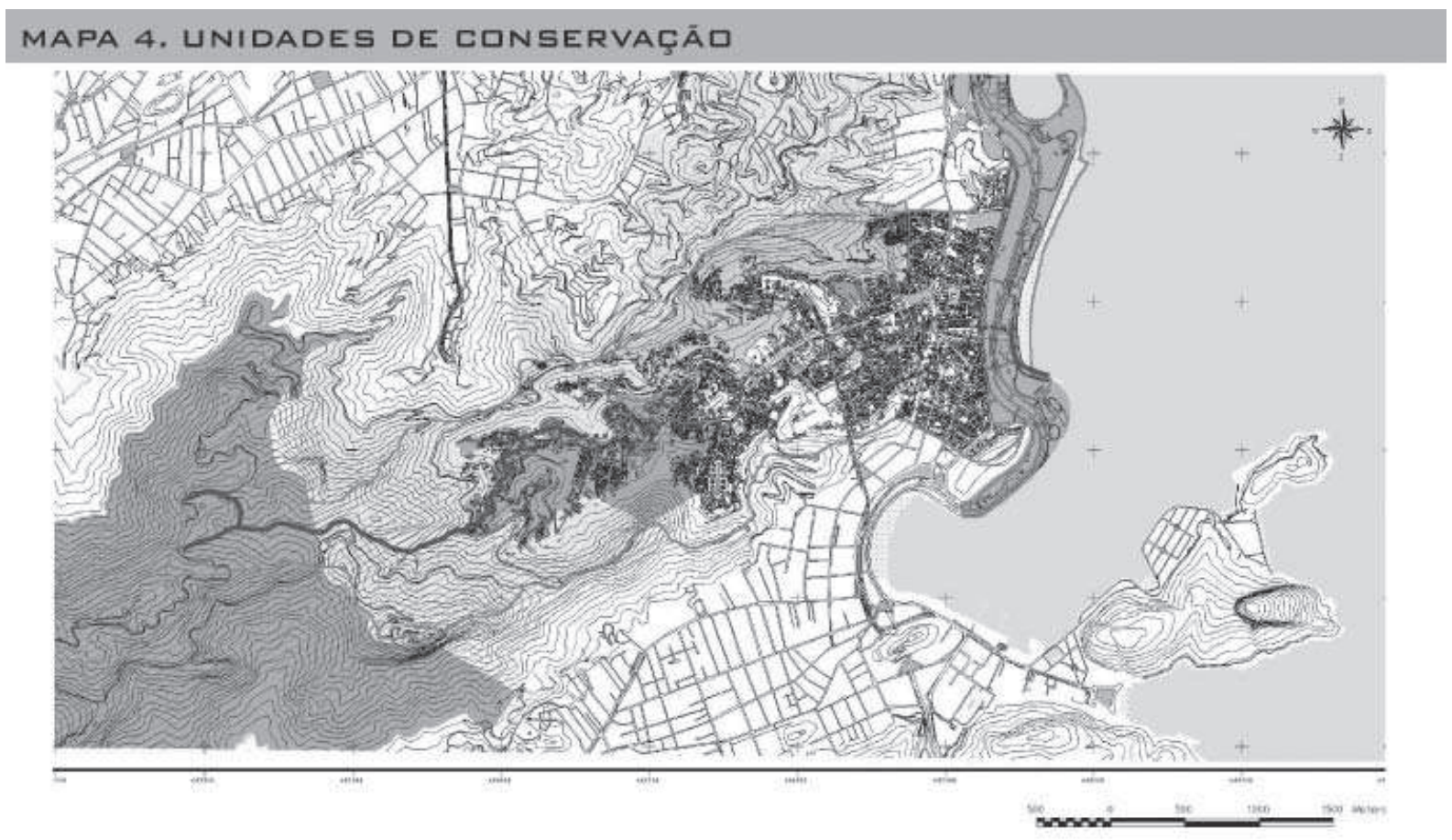

Parque Municipal do Flamengo 1981 APA de São José 1991

APA de Laranjeiras e Cosme Velho 1991
APAC de Santa Teresa 1984

APARU do Alto da Boa Vista 1992

Parque Nacional da Tijuca 1961

Mapa 4: As cinco primeiras unidades de conservação criadas na bacia do rio Carioca

Fonte: Schlee, 2002, sobre levantamento aerofotogramétrico, 1999, Armazem de Dados/ IPP - PCRJ

Em âmbito federal, já se encontravam protegidos o Parque Nacional da Tijuca (1961) e o Parque do Flamengo (1965). A criação destas sete áreas de proteção ambiental e cultural (APAs e APACs) na bacia do Carioca, funcionaram como instrumentos de proteção ao patrimônio cultural e natural, contendo a ocupação desenfreada das áreas formais nas encostas do vale. O reinício do programa municipal de reflorestamento para toda a cidade a partir de 1986 voltou a ter um impacto positivo nas encostas do vale, ajudando a refrear a perda de áreas remanescentes de cobertura vegetal. 
O papel desempenhado pelas diversas organizações não governamentais, em especial, as associações de moradores dos bairros de Laranjeiras, Cosme Velho, Flamengo e da Comunidade Guararapes, foi fundamental na construção da conscientização da comunidade a respeito dos valores históricos, culturais e ambientais. Entre as metas para melhoria da qualidade do Rio Carioca, aspiradas pela comunidade local organizada, constavam a retirada das chamadas "línguas negras" da Praia do Flamengo e a desobstrução das galerias subterrâneas do Rio Carioca, causada pelo despejo clandestino de resíduos sólidos no canal do rio e galerias de drenagem. Esta pressão da comunidade pela melhoria das condições ambientais do Carioca traduziu-se, na visão do poder público municipal e estadual, na construção de uma galeria de cintura em 1992, que desviou o curso ainda poluído do Carioca e captou as águas também poluídas de outros pequenos braços do Rio Catete que desaguavam na Praia do Flamengo, deslocando sua foz para um enrocamento nas proximidades, para dar fim às língua-negras que manchavam esta praia.

Em relação às condições da floresta, tal como aconteceu na cidade como um todo, o desenvolvimento urbano no vale do Rio Carioca levou a um progressivo avanço da malha urbana sobre a floresta tropical nas encostas do vale.

Mas, segundo os dados da avaliação ambiental e paisagística realizada em 2002 na bacia do Rio Carioca (Schlee 2002 e no prelo), que envolveu análises do uso do solo e da cobertura vegetal entre 1972 e 2002, a taxa de retração da floresta nesta bacia sofreu uma desaceleração no período entre 1984 e $2002^{5}$.

Em relação às condições morfológicas e ecológicas do rio, as recentes intervenções não trouxeram avanços. A estação de tratamento primário de esgotos instalada junto a sua foz pelo poder público estadual em 2002 até hoje não entrou em pleno funcionamento.

trecho final do rio junto à foz, dentro dos limites do Parque do Flamengo, foi encoberto por um deck de madeira em uma intervenção da Prefeitura da Cidade do Rio de Janeiro em 2004 (Figura 6), obstruindo o contato visual da população com o rio e tornando ainda mais difícil qualquer contato físico com as suas águas. $\bigcirc$ Carioca continua completamente degradado por despejo de esgoto domiciliar, até desaguar na Baía de Guanabara.

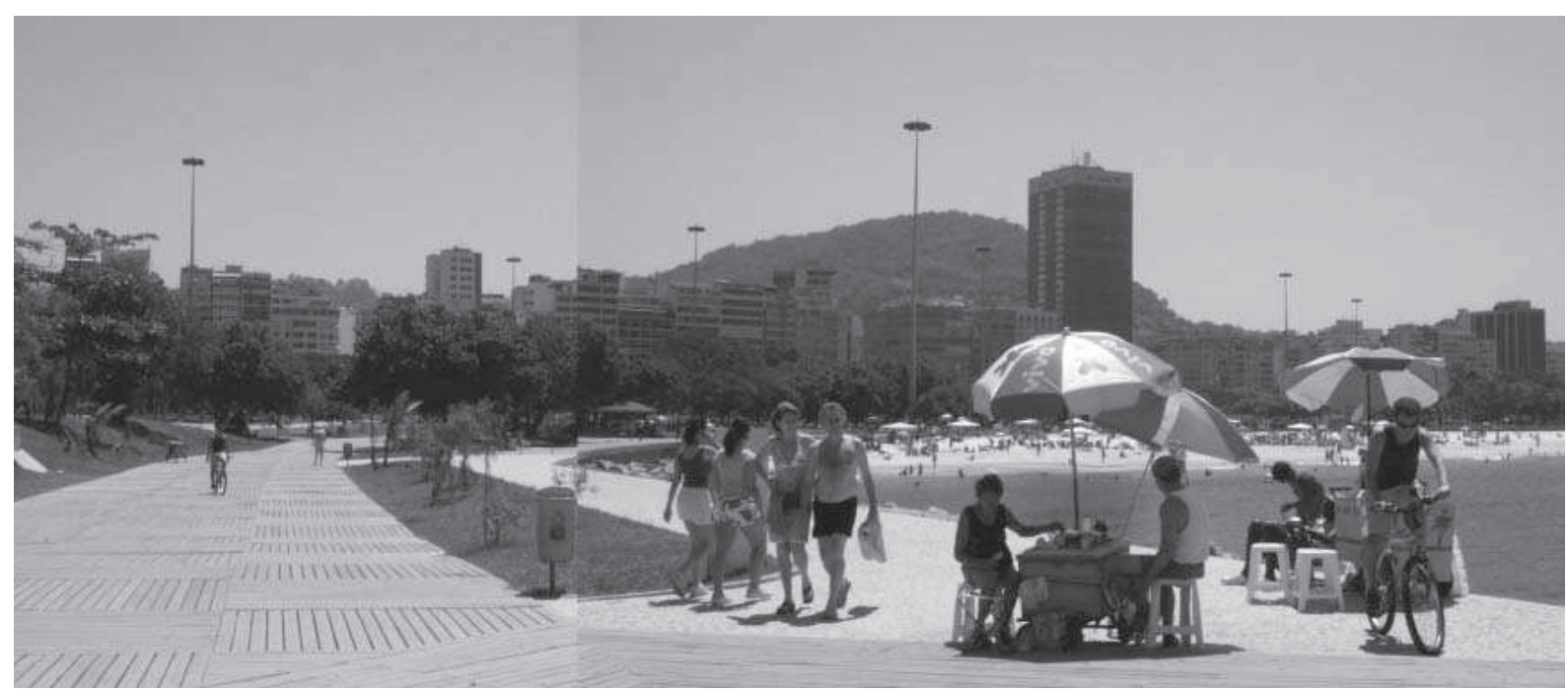

Figura 6: Recobrimento do leito do rio Carioca em 2004

Fotos: Schlee, outubro 2005

\section{Conclusões}

A perspectiva histórica apresentada neste trabalho revela a relação entre a cidade e seu suporte ambiental como um processo em contínua transformação, cujo percurso descreve um 
movimento que alterna aproximações e afastamentos. As condições ambientais e paisagísticas atuais da bacia do Rio Carioca refletem bastante bem os efeitos da herança paisagística legada pelas intervenções humanas no manejo da paisagem local. Quanto maior a transformação na paisagem, conforme os padrões de urbanização existente, mais intensos e negativos os efeitos na qualidade ambiental local.

A correlação entre os resultados dos estudos realizados em 2002 e a análise histórica sugere, no entanto, que a ação dos movimentos sociais organizados na conscientização ambiental e sua participação nos esforços de reflorestamento que tiveram lugar no vale do Rio Carioca no início dos anos 1990, a promulgação pelo governo municipal de leis ambientais a partir de 1984, com a criação de unidades de conservação e áreas de proteção ambiental e o início do programa municipal de reflorestamento a partir de 1986 podem ter contribuído para a desaceleração do processo de retração da floresta local.

Tal qual ocorreu no final do século XIX, esses resultados indicam que as intervenções humanas podem ser ativamente restauradoras e, ao mesmo tempo, preventivas, ao invés de apenas destrutivas. Essa é uma importante lição a ser aprendida e aplicada na gestão da paisagem de outras sub-bacias da cidade.

A experiência local durante as décadas de 1980 e 1990 demonstrou que ações conjuntas $\mathbb{Q}$ comunidade-administração pública $\bigotimes$ podem ter efeitos positivos sobre o ambiente urbano. Inversamente, as intervenções públicas levadas a cabo pelas administrações estaduais e municipais mais recentemente junto à foz do Carioca demonstram que os rios urbanos cariocas ainda são considerados como problemas e obstáculos a serem transpostos e seus atributos cênicos e ecológicos dificilmente são considerados pelo poder público como elementos de valorização da paisagem urbana carioca.

Ainda que progressos significativos tenham sido alavancados pela comunidade local e pelo poder público em direção à construção de uma consciência coletiva dos valores históricos, culturais e ambientais, o Rio Carioca e seu vale continuam a sofrer os mesmos problemas sociais e ambientais que assolam a cidade como um todo e que tendem a aprofundar-se se futuras abordagens de planejamento e gestão do ambiente urbano continuarem a seguir os mesmos padrões.

As ações governamentais ainda continuam prejudicadas pela falta de consenso do que constitui um ambiente urbano saudável, pelas disputas entre os órgãos municipais e estaduais em relação a atribuições e papéis no manejo do rio e pela permanente insuficiência de suporte financeiro para as iniciativas de recuperação. Uma solução ambientalmente responsável para a regeneração do Rio Carioca ao longo de todo o seu curso ainda não foi levada a cabo.

\section{Notas}

(1) Os dois documentos jurídicos que costumavam embasar a fundação de novos assentamentos portugueses - o Foral e o Regimento - que deveriam constar entre os documentos pertencentes à expedição de fundação da cidade nunca foram encontrados, assim como não restou nenhum documento com a demarcação das primeiras sesmarias da cidade após o incêndio que destruiu o Arquivo da Câmara em 1790 (Cavalcanti 1997, Abreu 2001).

(2) A Décima Urbana correspondia a $10 \%$ do valor da propriedade dentro do perímetro urbano.

(3) Segundo Cavalcanti, este debate iniciou-se em 1798, em uma reunião entre médicos e membros da Câmara Municipal, onde foi discutida a correlação entre temperatura, umidade, baixas condições de higiene urbana e a ocorrência de epidemias e foram indicadas recomendações que viriam a orientar as intervenções urbanas nos séculos XIX e XX (Cavalcanti 1997).

(4) Na verdade, sucessivos aterros foram executados com as terras provenientes do desmonte dos morros do Castelo, em 1922, e de Santo Antônio, em 1954 (Abreu 1987).

(5) O processo de declínio da floresta, que foi bastante intenso entre 1972 e 1984, arrefeceu entre 1984 e 1996 , diminuindo ainda mais entre 1996 e 2002 (Schlee 2002 e Schlee, no prelo). 


\section{Bibliografia}

ABREU, Maurício de Almeida. Geografia da cidade do Rio de Janeiro. Rio de Janeiro: Instituto de Geociências/UFRJ, 2001.

A cidade, a montanha e a floresta. In: ABREU, Maurício de Almeida (Org.). Natureza e sociedade no Rio de Janeiro. Rio de Janeiro: Secretaria Municipal de Cultura, 1992. (Coleção Biblioteca Carioca).

A evolução urbana do Rio de Janeiro. Rio de Janeiro: IPLANRIO/Zahar, 1987.

AMADOR, E. S. Baía de Guanabara e Ecossistemas Periféricos: Homem e Natureza. Rio de Janeiro: Edição do autor, 1997.

AQUINO, Lia. Santa Teresa: A cidade na montanha. Rio de Janeiro: Secretaria Municipal de Cultura, 1990. (Coleção Bairros Cariocas).

ARQUIVO NACIONAL. Tombo das cartas de sesmarias do Rio de Janeiro 1594-1595 e 1602-1605. Rio de Janeiro: Arquivo Nacional, 1967.

BARREIROS, Eduardo Canabrava. Atlas da evolução urbana da Cidade do Rio de Janeiro - 1565-1965. Rio de Janeiro: IHGB/Serviço Geográfico do Exército, 1965.

BENCHIMOL, Jaime Larry. Pereira Passos - Um Haussman tropical: As transformações urbanas na cidade do Rio de Janeiro no início do século XX. Rio de Janeiro: COPPE/UFRJ, 1982; PCRJ/SMC, 1991.

BERNARDES, Lysia M. C.; SOARES, Maria Therezinha Segadas. Rio de Janeiro: Cidade e região. Rio de Janeiro: Secretaria Municipal de Cultura, 1987. (Coleção Biblioteca Carioca).

BRASIL, Gerson. História das ruas do Rio de Janeiro. 5. ed. Rio de Janeiro: Brasiliana/Lacerda Editores, 2000.

CARVALHO, Maria Alice Rezende de. Quatro vezes cidade. Rio de Janeiro: Sette Letras, 1994.

CAVALCANTI, Nireu Oliveira. O Rio de Janeiro setecentista: A vida e a construção da cidade, da invasão francesa à chegada da corte portuguesa. Rio de Janeiro: Jorge Zahar Editor, 2004.

Folha da laranjeira. Informativo da Associação de Moradores e Amigos de Laranjeiras - AMAL, Rio de Janeiro, mar./abr., 1999.

. A cidade de São Sebastião do Rio de Janeiro: As muralhas, sua gente, os construtores (1710-1810). Rio de Janeiro: IFCS/UFRJ, 1997.

Biblioteca Carioca).

Natureza e sociedade no Rio de Janeiro. Rio de Janeiro: Secretaria Municipal de Cultura. 1992. (Coleção

CRANDELL, Gina. Nature pictorialized: The view in landscape history. Baltimore: The Johns Hopkins University Press, 1993.

CESAR, Paulo Bastos; OLIVEIRA, Rogério Ribeiro de. In: CRUZ, P. O. et al. (Ed.) A floresta da Tijuca e a cidade do Rio de Janeiro. Rio de Janeiro: Nova Fronteira, 1992.

DIAS, Ondemar. O índio no Recôncavo da Guanabara. Revista IHGB: Rio de Janeiro, p. 399-630, 1998.

FLORENTINO, Manolo Garcia. Em costas negras: Uma história do tráfico atlântico de escravos entre a África e o Rio de Janeiro - Séculos XVIII e XIX. Rio de Janeiro: Arquivo Nacional, 1995.

GASPAR, Madu. Sambaqui: Arqueologia do litoral brasileiro. Rio de Janeiro: Jorge Zahar Editor, 2000. (Coleção Descobrindo o Brasil).

GEOHECO-UFRJ/SMAC-PCRJ. Estudos de qualidade ambiental do geoecossistema do Maciço da Tijuca: Subsídios à Regulamentação da APARU do Alto da Boa Vista. Rio de Janeiro: PCRJ/SMAC, 2000.

GRAHAM, Maria. Diário de uma viagem ao Brasil. São Paulo: Edusp, 1990. (Coleção Reconquista do Brasil).

HADDOCK LOBO, Roberto Jorge. Tombo das terras municipaes, patrimonio da Illustrissima Camara Municipal da Cidade de São Sebastião do Rio de Janeiro. Letras da Câmara. Rio de Janeiro: Typographia Paula Brito, 1861.

HEYNEMANN, Cláudia. Floresta da Tijuca: Natureza e civilização, 1995. (Coleção Biblioteca Carioca).

MACEDO, D. Leite de. Livro de Tombo do Colégio de Jesus do Rio de Janeiro. Anais da Biblioteca Nacional, v. 82. Rio de Janeiro: Biblioteca Nacional, v. 82, 1968.

MAGALHÃES CORREA, Armando/Instituto Histórico e Geográfico Brasileiro. Terra carioca: Fontes e chafarizes. Revista do Instituto Histórico e Geográfico Brasileiro, 1939. 
McCANN, Joseph. Before 1492: The making of the pre-columbian landscape. Ecological Restoration, v. 1, n. 17, p. 15-30, 1999.

MENNEH, Marcia Halluli. Morfologia da paisagem verticalizada: Conflitos e padrões urbanísticos. 1997. Dissertação (Mestrado) - Faculdade de Arquitetura e Urbanismo, Universidade de São Paulo, São Paulo, 1997. 1999. . Before 1492: The making of the pre-columbian landscape. Ecological restoration, v. 3, n. 17, p. 107-1 19,

PCRJ. Código de Obras do Município do Rio de Janeiro. Rio de Janeiro: Gráfica Ariverde Ltda, 2000.

PEREIRA, Sônia Gomes. A reforma urbana de Pereira Passos e a construção da identidade carioca. Rio de Janeiro: UFRJ/ ECO/EBA/CAA, v. 2, 1996. (Série Dissertações e Teses).

REIS, José de Oliveira. O Rio de Janeiro e seus prefeitos. Rio de Janeiro: PCRJ, 1977.

RESENDE, Renato. Memórias e curiosidades do bairro de Laranjeiras. Rio de Janeiro: Amazon/João Fortes Engenharia, 1999.

SANTOS, Paulo F. Quatro séculos de arquitetura. Rio de Janeiro: IAB, 1981.

SCHLEE, Mônica Bahia; COELHO NETTO, Ana Luiza; TAMMINGA, Kenneth. Mapeamento ambiental e paisagístico de bacias hidrográficas urbanas: Estudo de caso do Rio Carioca. In: LUCIA Costa, M. S. A. (Org.). Rios e paisagem urbana em cidades brasileiras. Rio de Janeiro: PROURB/UFRJ/FAPERJ, no prelo.

SCHLEE, Mônica Bahia. Landscape change along the carioca river, Rio de Janeiro, Brazil. Landscape Architecture Thesis. University Park: The Pensylvania State University, 2002.

SEGAWA, Hugo. Ao amor do público: Jardins no Brasil. São Paulo: Nobel, 1996.

SZCZYGIEL, Boni; HEWITT, Robert. 19 $9^{\text {th }}$ century medical landscapes: John H. Rauch, Frederick Law Olmstead, and the search for salubrity, The Bulletin of Medical History, v. 4, n. 7, p. 708-734, 2000.

VAZ, Lilian Fessler. Uma história da habitação coletiva na vidade do Rio de Janeiro - Estudo da modernidade através da moradia. São Paulo: FAUUSP, 1994.

VIANNA, Hélio. Vale das Laranjeiras e Cosme Velho: Um recanto da Mata Atlântica. Rio de Janeiro: Secretaria Municipal de Cultura/Departamento Geral de Patrimônio Cultural, 1993.

VIEIRA FAZENDA, José. Antiqualhas e memórias do Rio de Janeiro. Rio de Janeiro: IHGB, 1921.

WARD THOMPSON, Catharine. Historic american parks and contemporay needs. Landscape Journal, ano 1, n. 17 , p. 1-25, 1998. 
